\title{
Populist Success in a Hung Parliament: The 2018 general election in Italy ${ }^{1}$
}

\section{Alessandro Chiaramonte, Vincenzo Emanuele, Nicola Maggini, Aldo Paparo}

Italy went to the polls on 4 March 2018 in a general election whose outcome was highly uncertain until the very last day of the campaign. The three main contenders were the centre-right coalition led by Berlusconi and Salvini, the centre-left coalition headed by Renzi, and the Movimento 5 Stelle (M5S, Five Star Movement) - a populist, anti-establishment party founded by comedian Beppe Grillo and now led by Luigi Di Maio. Uncertainty surrounded the election outcome not only due to the employment of a new, untested electoral system, but also as a result of the very high percentage of undecided voters and the competitiveness of the main political groupings. According to the polls, none of them would get the majority of seats in Parliament required to form a government outright. Thus the next government was expected to be formed on the basis of post-electoral bargaining among parties - perhaps even leading to a parliamentary majority cutting across coalitional borders - and would likely include the mainstream parties from both left and right camps, that is, the incumbent Partito Democratico (PD, Democratic Party) and Forza Italia (FI, Go Italy) respectively.

Indeed, the election resulted in a hung parliament with no clear winner. The centre-right coalition came first, but was some way from claiming an absolute majority of seats. The M5S finished a close second behind the centre-right coalition, while the centre-left was left trailing behind. More surprisingly, however, both PD and FI sustained extremely heavy losses in terms of both votes and seats, leaving them no chance to form a government either by themselves or including the minor centrist parties. Indeed, the real winners of this election were the populist parties, first and foremost the M5S and the Lega Nord (Lega, Northern League), both of which made significant gains from the previous election, and which together received about $50 \%$ of total votes and more than $50 \%$ of total seats in both the Chamber of Deputies and the Senate. Thus, no government was possible without the support of at least one of these two parties.

In this article we will try to give an account of the 2018 general election and of its strange, largely unexpected outcome. More specifically, in the following sections we will analyse: 1) the

This is the accepted version of the following article: Chiaramonte, A., Emanuele, V. Maggini, N. and Paparo, A. (2018), Populist Success in a Hung Parliament: The 2018 general election in Italy, South European Society and Politics, Volume 23, Issue 4, pp. 479-501, which has been published in final form at https://doi.org/10.1080/13608746.2018.1506513. 
background to the election; 2) the coalition-building and candidate selection processes; 3) the electoral campaign; 4) the result of the vote, its geographical character, and individual shifts in voting; and 5) the implication of the election's outcome for change in the Italian political and party system. The final section will consist in a discussion about the prospects following the election.

\section{Background: Italy from 2013 to 2018}

After the electoral earthquake of 2013, when the old bipolar party system - that had emerged since 1994 - collapsed due to the vote shrinking of both the centre-right and centre-left coalitions and the success of new parties such as the M5S and Scelta Civica (SC, Civic Choice, the political formation created by the then Prime Minister Mario Monti), a turbulent legislature started. For the first time since 1994, no clear majority came out from the 2013 election. This led, in the course of the legislature, to the formation of three governments headed by a member of the PD (Enrico Letta, Matteo Renzi and Paolo Gentiloni, respectively) and supported by a heterogeneous parliamentary majority consisting of parties that had contested the election within the centre-left (PD), the centre (SC), and the centre-right (PDL and later its splinter Nuovo Centrodestra, NCD).

The election of Matteo Renzi as the leader of the PD in December 2013 was a crucial turning point in that two months later he replaced Enrico Letta as the Prime Minister and, by exploiting the massive popularity he had at that time (as shown by the $40.8 \%$ his party would obtain in the European Parliament election of May 2014), promoted a new season of political and economic reforms. The most important of these reforms was certainly the revision of the second part of the Italian Constitution, that aimed to conclude 'the never-ending' transition from "First" to "Second" Republic ${ }^{2}$.

In April 2016 the Parliament approved the constitutional reform promoted by the Renzi government, but without the two thirds majority required to avoid a confirmatory referendum. The long referendum campaign took place in a context where public opinion had shifted considerably compared to the previous years. Indeed, with the economy struggling to pull out of a prolonged stagnation, the ongoing crises in public finances, banking system and migration, and an unfavourable international and European context, the popularity of the government and of Renzi

\footnotetext{
${ }^{2}$ Intended as the signature achievement of the Renzi government, the constitutional reform sought to drastically reduce the powers of the Senate across most policy areas, transforming it into an indirectly elected body representing the local and regional authorities and consequently ending the symmetrical bicameralism that is so characteristic of the Italian political system.
} 
himself had declined dramatically. Moreover, for the opponents of the Prime minister and his government, the referendum was an occasion to remove both of them from office. The referendum vote, which was eventually held on 4 December 2016, was indeed more 'on Renzi' (Ceccarini and Bordignon 2017) rather than on the merits of the constitutional reform and its outcome was unequivocal, with the 'No' side obtaining 59\%. The immediate consequence of the referendum result was the resignation of Renzi as prime minister and his replacement in office by Paolo Gentiloni, the former minister of foreign affairs. But there was more than that.

The electoral campaign essentially started the day after the constitutional referendum and did not stop until the end of the legislature. The referendum outcome boosted the image of a selfreferential political class and fuelled even more an anti-establishment rhetoric and a further polarization of the party system. The parties that most contributed to, and capitalized from, this 'poisoned' political climate in which the country was heading towards the next general election were the M5S and the Lega, i.e. the populist parties (Tarchi 2015; Verbeek, Zaslove and Rooduijn 2018). In other words, it became immediately clear that once again, as already in 2013 , the establishment vs. anti-establishment conflict, between the 'privileged élite' and the 'common people', would have played a fundamental role in structuring voter preferences and party choices. In October 2017, just four months before the end of the legislature, in order to avoid holding the upcoming election under two different electoral systems in the two branches of Parliament, a new electoral law (nicknamed Rosatellum, after the name of its main proponent Ettore Rosato, member of the PD) was approved ${ }^{3}$. The new electoral systems of the Chamber of Deputies and of the Senate combine the first-past-the-post (FPTP) system in single-member districts (SMDs) for the allocation of about one third (232 and 116 in the Chamber and in the Senate, respectively) of the total seats, with proportional representation (PR) in multi-member districts (MMDs) for the distribution of two thirds of the seats (386 and 193). The remaining 12 seats in the Chamber and 6 in the Senate are reserved for Italians resident abroad and assigned to a constituency of 'Italians abroad'. The SMDFPTP and MMD-PR arenas of competition, however, are not independent, but are intertwined. Indeed, candidates in SMDs need to be backed by one or more party lists running for the PR seats. Moreover, voters get a 'fused' vote, meaning that a vote for a party list automatically extends to

\footnotetext{
${ }^{3}$ Had Parliament not passed the new electoral law, the 2018 Italian elections would have ended up being held under two different electoral systems, each resulting from a separate ruling by the Constitutional Court: the system for election to the Senate being based on the old Calderoli Law (in place until the 2013 election), as amended by Constitutional Court ruling no. 1/2014, and the system for the Chamber of Deputies being based on the Italicum Law (introduced in 2015 only for this parliamentary branch in anticipation of the change in the parliamentary structure provided for by the constitutional reform) as subsequently amended by Constitutional Court ruling no. 35/2017.
} 
the SMD candidate supported by that party list, and vice versa ${ }^{4}$. Moreover, as regards the allocation of PR seats, national thresholds of $10 \%$ and $3 \%$ are set, respectively, for coalitions of party-list votes and single party list votes ${ }^{5}$. A $20 \%$ regional threshold, as an alternative to the established $3 \%$ national threshold, is also set for party lists representing official ethnic minorities.

\section{Coalition building and candidate selection}

As we have seen, the new electoral law, although allocating most seats through a nationwide PR system, provided for the election of roughly one third of MPs in SMDs. This offered a strategic incentive to parties to form pre-electoral coalitions supporting joint candidates in the SMDs. As a consequence of the aforementioned thresholds set by the electoral law, coalitions had to avoid parties achieving less than $1 \%$ of total national (valid) votes. Their votes would be 'wasted', as they would not be used for the purposes of PR seats distribution. Conversely, parties with between $1 \%$ and $3 \%$ of votes would be ideal for coalitional allies. Their votes, although not being used by the party itself to get seats, would be utilised by partners for the allocation of seats among coalitions.

As synthetically shown in Figure 1, parties reacted differently to this incentive structure. The M5S maintained its strategic decision to maximize brand recognition, avoiding any potential blurring of its uniqueness and running on its own once again. The centre-right parties adopted the opposite strategy. They formed a unified coalition in all of the national SMDs for both chambers of Parliament ${ }^{6}$. Parties composing the coalition once again represented the four 'spirits' of the Italian centre-right, as created 25 years earlier by Berlusconi: the post-fascist area now represented by Fratelli d'Italia (FDI, Brothers of Italy); the post-Christian Democratic Noi con I'Italia-Unione di Centro (NCI-UDC, Us with Italy-Union of the centre); the pro-free market Forza Italia (FI) - Berlusconi's own party; and the Lega. The latter is now the oldest of Italy's existing political parties, but at the same time it represents the most innovative element of the coalition: it was a northern regionalist party at the origin of the Second Republic (Tronconi 2009), whereas it has now been transformed into a populist radical right-wing party (Tarchi 2018) with nationwide appeal, under Matteo Salvini's

\footnotetext{
${ }^{4}$ In the case of a coalition of parties supporting an SMD candidate, a vote for that candidate extends pro-quota to all the party lists belonging to the coalition, i.e., proportionally to the total votes each party list receives in that district.

${ }^{5}$ For each coalition, only those lists that have obtained at least $3 \%$ of the vote take part in the internal distribution of seats.

${ }^{6}$ The Lega only supported its own candidate - opposing the candidates of the rest of the centre-right coalition for both Senate and Chamber of Deputies - in the Aosta Valley.
} 
leadership 7 . The new, national strategy is exemplified by the elimination of the word 'Northern' from the party electoral symbol - on the ballots it was simply the Lega (with the additional indication of Salvini Premier).

The centre-left coalition lies in an intermediate position. Renzi's PD realized the need for a coalition posed by the SMD-FPTP arena. However, after the splitting off of the Movimento Democratico e Progressista (MDP, Democratic and Progressive Movement) from the PD following the 2016 constitutional referendum, the prospect of a united centre-left appeared unlikely, even more so after Renzi was re-elected PD party leader through open primaries held in April 2017. Indeed, Renzi's party leadership had been controversial and polarizing, and it had been explicitly mentioned among the reasons for their splitting off from the PD by the various fractions who left the party during the 2013-2018 legislature - MDP being the last chronologically, and the largest in terms of MPs. Numerous attempts were made to heal the centre-left's internal divisions, most prominently by centre-left leaders Prodi and Veltroni from behind the scenes, and openly by the former centre-left major of Milan Pisapia. All proved unsuccessful, however. PD and Liberi e Uguali (LEU, Free and Equal), the joint list of the MDP and other parties to the left of the PD, all ran for election separately. The PD created a coalition with three allies: Lista Civica Popolare (CP, Popular Civic List), a joint list of several small centrist parties led by Beatrice Lorenzin, who had abandoned Berlusconi's party when the PDL withdrew its support to the Letta government and had served as Minister of Health under Letta, Renzi and Gentiloni; +Europa (More Europe) led by Emma Bonino, former EU commissioner and historical leader of several pro-civil rights campaigns; and Insieme (Together), a joint list of Greens, Socialists and 'Olive Tree supporters' (a grouping echoing the first centre-left winning 'Olive Tree' coalition).

\section{[FIGURE 1 ABOUT HERE]}

An additional actor deserves a mention in this overview of the electoral supply - the centrist pole led in 2013 by then Prime Minister and former EU commissioner Mario Monti. In the previous election, this pole received around $10 \%$ of valid votes in both chambers. However, in fall 2013 , Monti resigned from party leader, and party members began a diaspora mostly either towards Berlusconi's FI, or Renzi's PD. In the European Parliament election held in May 2014, the party had already lost

\footnotetext{
${ }^{7}$ Matteo Salvini, a long-term militant and prominent political figure of the Northern League, became the federal secretary of the party in December 2013.
} 
over $90 \%$ of its electoral support. It survived in Parliament for the whole 2013-2018 legislature, as a crucial junior partner of the governments, but it did not run in the 2018 election.

After having set their format, the two main coalitions had to select joint candidates in the SMDs. Regular negotiations were held in order to allocate districts among coalitional partners. Within the centre-right coalition, roughly $42 \%$ of SMDs had a $\mathrm{FI}$ candidate, $32 \%$ had a Lega candidate, $15 \%$ of the SMDs were assigned to FDI, and the remaining $10 \%$ to the NCI-UDC. These quotas were agreed on the basis of the expected vote for each party and thus represent the respective pre-electoral weights of those parties within the coalition: FI was larger than the Lega, and the moderate wing (FI+NCl-UDC) was larger than the sovereignists (Lega and FDI).

Within the centre-left, the PD had nearly $90 \%$ of the coalition's SMD candidates, with each of the other centre-left allies receiving a handful of SMDs for their respective candidates. Some coalitional candidates were highly debated, especially in the media. For instance, the choice of Berlusconi's former ally and right-wing Christian-Democrat Casini for the Senate in Bologna - the 'red city', where the left forces have traditionally been hegemonic. A similar case was represented by the appointment of Lorenzin to run as centre-left unified candidate for the Chamber of Deputies SMD in nearby Modena. A further candidacy decision concerning a minister was particularly prominent. It concerned Maria Elena Boschi, former minister of Institutional reforms in the Renzi government, who had become particularly unpopular over time, especially for her role in managing bank crisis in which her father was personally involved. In the end, though Tuscan, she was chosen to be the centre-left candidate in Bolzano, a safe SMD thanks to the support of the Südtiroler Volkspartei, SVP, an autonomist political party in South Tirol ${ }^{8}$. A final note concerns the decision to have 12 ministers (out of a total of 19) from the incumbent Gentiloni Government running in the SMDs (only two ran solely in the PR arena, while the remaining ministers did not participate in the election).

Only the M5S based part of the candidate selection process on democratic mechanisms. Certified members could vote for candidates to be included in the PR closed lists. Roughly 40,000 people participated in these primaries, called parlamentarie. These online primaries were held on the IT platform of the Rousseau Association, headed by Davide Casaleggio, president of the web

\footnotetext{
${ }^{8}$ In the media, all centre-left SMD candidates were portrayed as PD candidates, given the dominant role of the PD within the coalition.
} 
marketing company Casaleggio Associati (Deseriis 2017) ${ }^{9}$. The transparency of the voting procedures on this platform, and the protection of users' data, remain a hotly-debated, controversial issue, nevertheless. Candidates for the SMDs on the other hand, were chosen by the M5S's political leader Luigi Di Maio ${ }^{10}$, following consultation with Beppe Grillo, from among incumbent MPs and citizens who, on a district basis, put themselves forward for selection. The latter lists included 'well known' people such as the TV journalists and sport champions. The M5S was faced with two problems with its candidates during the course of the campaign. In the case of incumbent MPs, a TV investigation revealed that some of them had not complied with the internal reimbursement system, whereby part of their salaries was to be devolved to a fund providing loans to business start-ups. In the case of certain new M5S candidates, on the other hand, investigations revealed that some of them have lied with regard to past or present criminal charges, as well as on questions of membership of other parties or masonic lodges, which is forbidden by the M5S's internal regulations.

\section{The electoral campaign}

Turning now to the electoral campaign, we can start by pointing out that, given the way it was conducted, voters perceived the competition among coalitions as a battle for national government, rather than for local candidates in the SMDs. The limited impact of individual candidates on the electoral results was also exacerbated by the ballot paper design required by the new electoral law, which relegated candidates' names to a smaller area than that of the parties' symbols.

In general, parties focused more on conflict than problem solving. Our data on tweets indicate that two-thirds of policy-related contents produced by political actors concerned positional issues rather than valence $\mathrm{e}^{11}$, and in particular the economy (30\% of total tweets) and immigration (20\% ${ }^{12}$.

\footnotetext{
${ }^{9}$ Davide Casaleggio is the son of Gianroberto Casaleggio, the web entrepreneur who founded with Beppe Grillo the M5S in 2009. When the father died in 2016, the son became the head of Casaleggio Associati, the web company running the internet website of the Movement, and a crucial figure within the M5S organization.

${ }^{10}$ Luigi Di Maio was a MP for the M5S elected in 2013. He served as the vice-President of the Chamber during the 20132018 legislature. Since September 2017, he has been the formal political leader of the M5S, following his victory in the online primaries.

${ }^{11}$ Positional issues are those on which political actors and voters hold different positions (level of taxes vs. level of welfare services). On the contrary, valence issues are those on which, by definition, all parties and voters agree (i.e. fight against corruption, or protection from terrorism). See Stokes (1963).

${ }^{12}$ We have collected and coded tweets by all parties and party leaders during the two months before the March 4 election. This was done as part of an international comparative research project. These findings place Italy in an
} 
The various different actors concerned campaigned by taking up a position in regard to these two areas of policy. The centre-right (subject to certain internal specificities) pushed for a tougher stance on immigration and for a flat taxation system deemed capable of fostering economic growth; the M5S's most prominent proposal concerned the reddito di cittadinanza (public-funded monthly basic income) for people below poverty threshold, while it maintained an intermediate position on immigration; the centre-left, on the other hand, campaigned for the continuity of economic policies (accompanied by forms of welfare support for the poor), and for a reduction in immigration flows, which had already been pursued by the Renzi and Gentiloni governments. Confirmation of the desire to campaign on the basis of the record of the incumbent cabinet, is provided by the aforementioned decision to candidate ministers in SMDs in order to maximize their public visibility.

It is worth underlying that the European dimension was not at all prominent during the electoral campaign. This appears particularly interesting if we consider the post-electoral developments towards a M5S-Lega government, in which Europe acquired a centre-stage role. This was definitely not the case for the electoral campaign. Overall, out of roughly 1,300 policy tweets we have collected and coded, less than $8 \%$ concerned the EU, the euro, or the EU economic policy, and less than $5 \%$ the EU per se. For two of the three main actors, such strategic decision to silence the EU dimension makes sense, after all. Both the M5S and the centre-right coalition had internal clashes on the EU. In the centre-right, there was the coexistence of clearly pro-European figures (such as the former EU commissioner and EP President Tajani, candidate Prime Minister for FI), with euro-skeptical, if not openly anti-EU ones (especially in the Lega). Ambiguity was also present within the M5S ranks. For the centre-left, a clearly pro-EU actor, the choice of silencing the European dimension is less easily understandable. It probably has to do with the perceived unpopularity of the EU in the eyes of Italian voters, which made the party believe that campaigning on it would not have been electorally beneficial.

One event which occurred during the electoral campaign describes its political climate quite well. On January 31st, police discovered the body of a young woman who had been missing after leaving a nearby rehab facility, outside the town of Macerata. The next day a Nigerian man with a criminal record for drugs was arrested and charged with her murder. On the morning of February 3rd, an Italian man drove his car through the streets of Macerata shooting black people as he went, injuring six of them. After his arrest, it emerged that in 2017 he had run in the municipal election

intermediate position (De Sio and Paparo 2018): positional issues are much more salient than in the UK and France, but less so than in the Netherlands. Italian results appear very similar to Austrian and German. 
held in a small town near Macerata, as a Council candidate for the Lega Nord (as it was still called at that time). Salvini was accused (by writer Roberto Saviano among others) to having politically instigated the assault as a result of his strong anti-immigrant rhetoric. He replied to this potentially harmful event by saying that, although violence had to be condemned, uncontrolled immigration had brought about social conflict, and by promising that his cabinet would make Italy's towns and cities safe places once again (!). At the polls, voters proved that they sympathised with this view by providing Salvini's party with its best electoral result ever, as we shall see.

Overall, we can say that the 2018 electoral campaign was a rather 'poor' one in a number of different ways. This was the first electoral campaign since the elimination of electoral reimbursements in 2014, which drastically reduced parties' ability to organize their campaigns, in terms of both large-scale events, and also door-to-door get-out-and-vote tactics. The campaign was mostly fought on TV, but without any actual debate among the leading candidates ${ }^{13}$. Internet and social media were systematically employed by candidates and parties to convey their messages directly to voters, whereas public spaces and speaking were basically absent from the picture. This was nothing new for mainstream parties, which had already declined to use open public spaces in 2013; however, it provided a novelty for the M5S, which five years beforehand had built its election campaign on Beppe Grillo's appearances in town squares around Italy - the so-called 'Tsunami Tour $^{14}$.

The campaign was also fought on the post-electoral prospects. It was quite clear that none of the three competing poles was going to reach a majority of MPs, which would have required some kind of post-electoral agreement to form and support a government. Many observers considered the agreement between the PD and FI as the most probable outcome, which would have resulted in a kind of grand-coalition government. Both the PD and FI were very careful in denying such possibility, which was negatively perceived by voters. However, it was frequently brought up by their opponents in order to mobilize voters against such outcome, depicted as a possible further violation of the democratic electoral process. In particular, the M5S, the Lega, and FDI claimed that voting for them was the only choice to prevent your vote to help Renzi going back to Palazzo Chigi.

\footnotetext{
13 The only exception was the face-to-face encounter between the Lega leader Matteo Salvini, and Laura Boldrini, incumbent President of the Chamber of Deputies and a prominent figure in the LEU, during the current affairs talk-show 'Otto e Mezzo' on February $13^{\text {th }}$.

${ }^{14}$ The sole exception being that of the M5S, once again concluding its electoral campaign in Rome's Piazza del Popolo, on March $2^{\text {nd }}$; however, the square was not as full as it had been five years earlier.
} 


\section{The results}

Turnout, votes and seats. According to the polls, a significant drop in the turnout rate was to be expected, not only because of the bad weather in many parts of the country, but mainly because of the anti-political climate. Turnout was actually $72.9 \%$, a record low for Italian general elections held since 1948. Nevertheless, it only fell by 2.3 percentage points, as can be seen from Figure 1: the decline was much more marked in the previous elections held in 2013 , when turnout was down by 5.3 percentage points ( 2.5 million voters) compared to the election of 2008 . Hence, turnout fell to a lesser extent than many observers had expected, and this decline could be seen as of a physiological nature due mainly to generational replacement - new voters voting less than older ones (socialized after WW2 at a time of mass mobilization), progressively exiting the electorate. Indeed, the graph shows that turnout at elections in Italy has been falling since 1979 at an average rate of 0.5 points per year. Moreover, compared to the turnout registered in the most recent national elections of other major European countries (France, UK, Spain, Germany), Italian turnout was only lower than that of Germany.

[FIGURE 2 ABOUT HERE]

As regards the outcome of the election, a comprehensive analysis of the results needs to distinguish not only between the Chamber and the Senate, but also between the arenas in which the counting of votes serves the purpose of deciding the attribution of seats to coalitions and single lists: the PR arena, the FPTP arena, and the 'abroad' constituency. Table 1 summarizes the final distribution of votes in the domestic aren ${ }^{15}$ for both chambers, and also the distribution of seats in the three aforementioned arenas for each chamber.

\section{[TABLE 1 ABOUT HERE]}

The first finding emerging from Table 1 is that the two chambers show very similar results, contrary to 2013 when there were two different electoral systems for the two chambers of Parliament, and results were quite different., In particular, among voters under the age of 25, who

\footnotetext{
${ }^{15}$ It includes valid votes in the Aosta Valley's SMD (1 seat at stake in each chamber).
} 
can vote only for the Chamber, the M5S was largely over-represented. As a result, in 2013, the M5S did significantly better in the Chamber than in the Senate (D'Alimonte 2013).

The results should be read separately for coalitions and single lists. In the first instance, the winning coalition is that of the centre-right, with $37 \%$ of the votes in the Chamber of Deputies and $37.5 \%$ in the Senate, but with no absolute majority of seats. The centre-left coalition led by the PD only came in third, with around $23 \%$ of the votes in both chambers. The real novelty, however, was the success of Di Maio's independent list, the M5S, which came second with almost 11 million votes in the Chamber of Deputies (32.7\%) and almost 10 million votes in the Senate (32.2\%), making it the most voted-for individual party. Thanks to the presence of the FPTP mechanism, the successes of both the centre-right coalition and the M5S were amplified in terms of seats: the centre-right was assigned 265 seats (42.1\%) in the Chamber of Deputies and 137 (43.5\%) in the Senate, while the M5S was assigned 227 seats (36\%) in the Chamber of Deputies and 112 (35.6\%) in the Senate. Conversely, the centre-left is under-represented, obtaining 122 seats in the Chamber of Deputies $(19.4 \%)$ and 60 (19.0\%) in the Senate. The other independent list that obtained seats in Parliament by means of its exceeding the $3 \%$ threshold, was LEU, with $3.4 \%$ of votes for the Chamber of Deputies and 3.3\% for the Senate. This left-wing party did not win in any of the SMDs, getting only 14 proportional seats $(2.2 \%)$ in the Chamber of Deputies and 4 seats $(1.3 \%)$ in the Senate.

As far as the performance of single lists is concerned, the M5S, as mentioned, was by far the largest party, more than 13 percentage points ahead of the second party, the PD. The PD - the party of former Prime Minister Matteo Renzi - achieved its worst ever result, obtaining around just 19\% of total votes ( $18.7 \%$ in the Chamber of Deputies and $19.1 \%$ in the Senate) and 112 seats (17.8\%) in the Chamber of Deputies (and a similar share in the Senate, giving it 53 seats). The party's performance was particularly disappointing in the FPTP arena, where it only got 21 seats (9.1\%) in the SMDs of the Chamber of Deputies (and an even lower share, 6.9\%, in the Senate). Conversely, M5S won in around $40 \%$ of the SMDs (93 seats) in the Chamber of Deputies and in a similar share in the Senate (37.9\%). This performance in the FPTP arena is similar to that of the centre-right coalition, composed by several parties, which gives us an idea of just how successful the M5S was. The only arena where the M5S did not achieve a satisfactory result was the 'abroad' constituency, where it got only one seat in the Chamber of Deputies. Conversely, in this arena the PD was the most successful party, obtaining 5 seats in the Chamber of Deputies and 2 seats in the Senate.

As for the individual lists within the centre-right coalition, the most important result was the success of the Lega, which for the first time in its history overtook Berlusconi's party, thus becoming 
the third most voted party in the country with $17.3 \%$ of the votes, only 1.4 percentage points behind the PD, and with a total of 125 seats (19.8\%). Conversely, FI got around $14 \%$ of the votes and fewer seats than the Lega not only in the PR arena, but also in the FPTP arena. In the latter, the Lega got 50 seats, whereas FI won in 43 SMDs. In the Senate, the result was very similar. FDI is the other centre-right party that obtained seats, with $4.4 \%$ of votes in the Chamber of Deputies and 32 seats (13 in the plurality arena) and similar results in the Senate. The other national party in the centreright coalition, $\mathrm{NCl}-\mathrm{UDC}$, did not reach the $3 \%$ threshold, but got 5 seats in the Chamber of Deputies and 4 seats in the Senate thanks to strategic coalitional agreements with other parties during the selection of SMD candidates.

In this regard, the centre-right coalition's better performance compared to that of the centreleft, was also due to the very poor performance of the PD's allies: no such party reached the 3\% threshold (+Europa only managed $2.6 \%$ ), and only the $20 \%$ regional threshold for ethnic minorities was exceeded by the SVP in South Tyrol. The other centre-left lists (Insieme and CP) performed even worse, getting less than $1 \%$ of the vote and thus not contributing to the coalition's electoral total for the purposes of the allocation of PR seats. Nevertheless, in the FPTP arena, thanks to coalitional agreements, these parties, together with +Europa, managed to get a handful of seats in both chambers.

Votes and territory. The 2018 general election has resulted in further political turmoil after the political 'earthquake' of 2013 (Chiaramonte \& De Sio 2014). Both main anti-establishment parties (M5S and Lega) have achieved historical success, with a combined vote representing the absolute majority of votes cast. As regards the M5S, never before in the history of Western Europe has a new party obtained such a high degree of support in only its second appearance at a national election, improving its already historical success in $2013^{16}(+7.1$ percentage points, an increase of around 2 and a half million votes). The Lega obtained its best ever result in a general election, both in absolute and percentage terms, obtaining 4 million votes more (+13.2 percentage points) than in previous elections, and for the first time ever overtaking FI within the centre-right coalition, as previously mentioned. These historical electoral outcomes were accompanied by a paradigm shift that has thrown consolidated territorial alignments into disarray.

[FIGURE 3 ABOUT HERE]

\footnotetext{
${ }^{16}$ For an analysis of the M5S's success in the 2013 general election, see Maggini \& De Lucia (2014).
} 
Figure 3 shows the most voted coalition/party in the SMDs in 2018, compared to results for 2013 aggregated in the same districts. In 2018, Italy's central regions - the so-called 'Red Zone' where support for the PD has deep historical roots ${ }^{17}$ and where the PD controls numerous local administrations, turned out to be the most competitive geopolitical area of the country. The coalition led by the PD was defeated for the first time in its history throughout the entire 'Red Zone': the centre-right coalition won 19 FPTP seats against the PD's 16. The centre-left won only half of the SMDs in Tuscany (7 out of 14), and just over half in Emilia-Romagna (9 of 17). As the figure shows, the change from 2013 is a truly dramatic one. Moreover, the M5S confirmed its strength in the Marche (obtaining 35.6\% of the vote at regional level and winning in 5 SMDs). The success of the centre-right coalition was exclusively due to the incredible electoral rise of the Lega, which ranged from $17.3 \%$ of votes in the Marche and $20.2 \%$ in Umbria, whereas FI fell below the $10 \%$ mark in the central regions of Italy (except in Umbria where it won $11.2 \%$ of votes cast). Therefore, Salvini's strategy of transforming the Northern League into a national party proved very successful, considering that the Lega even achieved an average of $8 \%$ of votes in the South of Italy ${ }^{18}$.

In the South, which is traditionally the most competitive area of the country from an electoral viewpoint, the M5S is the predominant party except in Lazio (where the centre-right became the leading coalition). The M5S became the leading party in most southern SMDs (84), replacing both the centre-right (which won only in 13 SMDs located in Calabria and Campania) and the centre-left (which almost disappeared, winning only in four SMDs, all of which located in Rome). Therefore, the incredible success of the M5S is mainly due to its astonishing electoral rise in Italy's southern regions, where it obtained over $40 \%$ of the vote in all regions (except Lazio), with unprecedented peaks in Campania (49.5\%) and Sicily (48.7\%).

Finally, the North was once again dominated by the centre-right coalition (79 FPTP seats) ${ }^{19}$, again thanks to the noteworthy rise of the Lega, which obtained $32.8 \%$ of votes in the Veneto and $28.3 \%$ in Lombardy. This is also the only area of the country where the M5S performed worse than it had previously done in 2013, winning only in the Aosta Valley SMD, in two SDMs in Genoa and in

\footnotetext{
17 The Red Zone is made up of Emilia-Romagna, Tuscany, Marche, and Umbria. For a thorough examination of the characteristics of the 'red' sub-culture and of the electoral behaviour of voters in those regions, see Diamanti (2009) and De Sio (2011).

${ }^{18}$ Lazio, Abruzzo, Molise, Campania, Apulia, Basilicata, Calabria, Sicily, and Sardinia are included in the South.

${ }^{19}$ The North consists of the following regions: Aosta Valley, Piedmont, Lombardy, Trentino-South Tyrol, Veneto, FriuliVenezia Giulia, and Liguria.
} 
one in Turin, whereas the centre-left coalition won in the three SMDs of the South Tyrol (thanks to the electoral alliance with SVP), in three SMDs in Milan and in two in Turin.

The analysis of the vote shifts: where have voters gone? The great success of anti-establishment parties was accompanied by the historical defeat of the two mainstream centre-left and centre-right parties (PD and $\mathrm{FI}$ ), which together lost more than 5 million votes compared to the 2013 election. The PD lost around 2 and a half million votes (-6.7 percentage points), while FI lost almost 3 million votes (-7.7 percentage points) ${ }^{20}$. Meanwhile, the centrist coalition led by Mario Monti (Italian Prime Minister between 2011 and 2013) has disappeared. Where have all these votes gone? In order to give initial tentative answer to this question, we have analysed the vote shifts ${ }^{21}$ in 11 Italian cities.

\section{[TABLE 2 ABOUT HERE]}

The rows in Table 2 show the major cities we have selected (distinguishing between the North, the 'Red Zone' and the South), while the cells show the two most important destinations of votes in 2018 for all of the major parties/coalitions standing in 2013 (in columns), excluding any confirmation of 2013 (non)voting. The overall picture that emerges is ultimately understandable. First, the electoral crisis of the PD has been confirmed: though the party showed a certain ability to attract voters of the centrist coalition led by Monti and a limited ability to attract votes from the centreright, it failed on the other hand to prevent significant numbers of its voters turning away from the party to the M5S, or from abstaining altogether (especially in southern cities), and to the LEU as a second alternative. Secondly, the M5S only suffered defections to the Lega (especially in the North and in the 'Red Zone') and a certain degree of voter abstention. In turn, it attracted voters almost exclusively from the centre-left in the North and in the 'Red Zone', while in the South it also got votes among those who had abstained or had voted for the centre-right in 2013. In general, the centre-right (whose votes were mostly inherited by Salvini's party in central-northern cities) mainly saw certain previous voters abstaining this time around. Finally, those voting for Monti's coalition in 2013, as we have said, moved mainly towards the PD as their first choice destination, while their second-choice destinations were not only the PD's allies, but also centre-right parties (especially FI).

\footnotetext{
${ }^{20}$ It should be noted that in 2013, Berlusconi's party was called the Popolo della Libertà (PDL, People of Freedom). The party changed its name after a split in the centre. Similarly, the PD suffered a split on the left.

${ }^{21}$ The estimates have been produced using the Goodman model (1953) on polling-station data (Schadee \& Corbetta 1984).
} 


\section{The new Italian party system: volatility and de-nationalization}

As shown by our analysis of the electoral results, the 2018 general election radically changed the Italian political and party setting once again, following the 'critical' 2013 election (D'Alimonte, Di Virgilio \& Maggini 2013). In 2013, the massive shift in voters' preferences and the unpredictability in the patterns of inter-party competition, led scholars to call the Italian party system 'deinstitutionalized' after 2013 (Chiaramonte \& Emanuele 2014). This time, given both the persistence of the tripolar competition that emerged five years ago, and the absence of any major new political parties contesting the election, a degree of stabilisation was expected to be the most likely outcome.

Indeed, the 2018 election has produced elements of continuity both in terms of 'mechanics' and 'format' of the party system (Sartori 1976): the consolidation of the tripolar pattern of competition and the stabilisation of party system fragmentation. As regards the mechanics of the election, the three main political poles have together garnered $92.6 \%$ of the vote, which is about 8 percentage points more than in 2013. As regards the format, the effective number of electoral parties (Laakso \& Taagepera 1979) has remained stable at around 5, which is some way from the extremely high levels seen in the 1990s, but also from the quasi-two-party system witnessed in the 2008 general election - when the newly-founded PDL and PD collected more than $70 \%$ of votes.

Yet, beneath this apparent continuity, a new seismic wave has hit the Italian party system in 2018. Indeed, although it is true that the tripolar competition has been consolidated, the balance of power among the three political poles has radically changed, with the centre-left dropping from first to third position, the centre-right rising from second to first, and the M5S from third to second.

This significant change in the balance of power among the three main electoral poles is the result of two important phenomena, namely the persistence of significant electoral instability, and the resurgence of territory as a major determinant of Italy's voting patterns.

As regards electoral instability, Figure 4 displays the evolution of Pedersen's index of electoral volatility (1979) in elections for the Chamber of Deputies during the 1948-2018 period. ${ }^{22}$ This index

\footnotetext{
22 To calculate the index we followed the 'aggregation method' (Casal Bértoa, Deegan-Krause \& Haughton 2017) originally devised by Bartolini \& Mair (1990). It considers parties resulting from splits and mergers in continuity with their predecessors, thus reducing the potential pool of new parties to those political formations that are 'start-up organisations' (Emanuele \& Chiaramonte 2016). In the case of the 2018 elections, according to the criteria used, the two most relevant differences from 2013 have been the disappearance of SC and Fare per fermare il decline (Act to Stop the Decline) and the emergence of +Europa. All others new labels have been considered in continuity with some pre-
} 
shows that electoral volatility in Italy remained rather stable at somewhat low values during the First Republic, particularly between the end of the 1950s and the end of the 1980s. Then, the collapse of the First Republic and the start of the bipolar era led to a huge peak in volatility in 1994 (39.3), followed by another period of stabilisation during the 20 years of the Second Republic - albeit with higher levels of instability compared to the First Republic. Italy then experienced a new upsurge in volatility in the 2013 election, mainly due to the emergence of new political forces like the M5S and SC. In 2018, the index of volatility now stands at 26.7, the third highest level in Italy's electoral history.

\section{[FIGURE 4 ABOUT HERE]}

From a comparative perspective, the 2018 election represented the twelfth most volatile election in Western European history, taking into account a sample of 364 elections in 20 countries since 1945 (Emanuele 2015a). This statistic is even more important given that it is highly uncommon to experience two consecutive elections characterised by a high degree of volatility. Usually, in Western Europe a highly volatile election is followed by a period of stability. In this respect, the sequence 2013-2018 represents the second most volatile couple of elections in Western European history, after the Icelandic case in the 2013-2016 period. This lends support to the hypothesis of an on-going process of de-institutionalization of the Italian party system ${ }^{23}$. Compared to 2013 , volatility has decreased by 10 points, but this result is in some way even more relevant as it has been achieved within the context of a fairly stable electoral supply and no new important parties contesting the election. More specifically, while in 2013 most of the volatility was due to the successful emergence of new parties, in 2018 it is the shifts among existing parties that account for the lion's share of that volatility.

A second important phenomenon emerging from the 2018 election, and one that is strongly intertwined with the persistence of electoral instability, is the resurgence of territory as a major determinant of Italy's voting patterns. Indeed, the aforementioned shift in voters' preferences has not been uniform across the country. On the contrary, as the study of electoral geography shows,

existing party: LEU is in continuity with Sinistra, Ecologia e Libertà (SEL, Left Ecology and Freedom) and the PD; NCI-UDC is in continuity with the PDL and UDC; Potere al Popolo (Power to the People) is in continuity with Rivoluzione Civica (Civic Revolution).

${ }^{23}$ Indeed, all the necessary requirements for party system de-institutionalization - instability and unpredictability recurring over time (Chiaramonte \& Emanuele 2017) - seem to be met. 
the recent election was characterised by noticeable territorial differences in voting patterns, with the Lega emerging as the most voted force in the North (26.7\% of total votes), and the M5S dominating the South of the country (with a $43.4 \%$ share of votes). This historical change suggests that beneath the changing balance in power among the three major political forces at national level, lies another 'seismic wave' at local level. The analysis of the results in the SMDs of the Chamber of Deputies reveals the presence of three different patterns across the country. The North is a predominant-pole area, characterized by the dominance of the centre-right, with the M5S and the centre-left in general lagging some way behind the centre-right. The former 'Red Zone' has become the most competitive area of the country: a quasi-bipolar competition between centre-right and centre-left emerged in the 2018 election, with the M5S generally bringing up the rear. Finally, the South can be labelled as a predominant-party area, given the broad, significant success of the M5S. Hence, the southernization of the M5S and FI, the entrenchment of the PD in its former strongholds of Tuscany and Emilia-Romagna, and conversely, the significant strengthening of the Lega below the line of the Po River in the North, have all radically reshaped the features of the party system at territorial level.

[FIGURE 5 ABOUT HERE]

As Figure 5 shows, the overall result has been a substantial decrease in vote nationalization, conceived as the level of territorial homogeneity of the electoral support for political parties in a given party system (Caramani 2004; Emanuele 2018). It is measured through the standardised Party System Nationalization Score (sPSNS) developed by Bochsler $(2010)^{24}$. With the significant exception of the 1992-1996 period, where the emergence of the Lega contributed to a strong process of denationalization, during both the First and Second Republics Italy has displayed a rather nationalized party system. In comparative terms, Italy has a more territorially homogeneous degree of party support than other large Western European countries such as Germany, Spain and the UK (Emanuele 2018) - which runs counter to the emphasis on within-country territorial diversity usually put forward by Italian scholars (Galli et al. 1968; Diamanti 2009). The presence of parties with nationwide support - like the Christian Democracy or the Communist Party during the First Republic,

\footnotetext{
${ }^{24}$ The index is derived from the Gini coefficient, applied to the variation in the distribution of party support across territorial units. It ranges from 0 to 1 (the latter representing a case of perfect nationalization, meaning that each party received the same share of votes in all territorial units).
} 
FI (or the PDL) and the PD during the Second Republic, or even the M5S in 2013 - is an essential prerequisite for party system stability, since such parties are able to represent voters' preferences and meet demands from various different areas of the country. This is why many authors have linked the concept of nationalization to that of party system structuring or institutionalization (Sani 1992;

Chiaramonte \& Emanuele 2014; Lupu 2015; Emanuele 2015b). In Italy the two processes have usually gone hand in hand, with electoral stability accompanied by territorial homogeneity and vice versa (as in the 1992-1996 period). The 2013 election was an exception in this respect. The massive electoral change was not associated with any territorialization of party support, as the M5S truly cut across any geographical divisions. In 2018, the parallelism of the two processes reappeared. As Figure 5 shows, the sPSNS has dropped from 0.862 to 0.822 , the lowest level since 1996. Therefore, just as in the period 1992-1996, an on-going process of party system de-institutionalization is followed by vote de-nationalization. The similarity with that crucial period of change is a powerful sign of the fact that in 2018 the Italian party system is far from stable, and the point of arrival of this transitional phase is hard to foresee.

\section{Conclusions}

The outcome of the 2018 general election has confirmed the picture of fluidity of the Italian political system that had already emerged after the 2013 election. This fluidity has affected the electoral system, the political supply chain, voting behaviour and the party system.

After a frantic period characterized by numerous amendments to the electoral law, introduced by both Parliament and the Constitutional Court, the 2018 election was eventually held under a new, untested mixed electoral system, the third one used since 1993. This mixed system, however, is one where the overall weight of the majoritarian component is significantly diminished compared to previous systems, making it more likely that the election would result in a hung parliament with no clear winner. In fact, this is exactly what happened.

As regards the political supply, this election has revealed a significant degree of instability once again, after that of the 2013 election. While the main contestants in 2018 have remained substantially the same as those seen in 2013 - the centre-right, the centre-left and the M5S - the internal composition of the two coalitions as well as the label of many parties, have significantly changed, and the fourth pole seen in 2013, led by Mario Monti, has disappeared from the scene. 
The election has also confirmed the high individual mobility of voters. As the analysis of electoral shifts shows, the mobility of voters between 2013 and 2018 appears to be a much higher than the mere net changes in party votes recorded at the aggregate level. Moreover, many voters were uncertain what to do, deciding whether to participate in the election or not, and if so, what party or candidate to vote for, at the very last minute.

Finally, all these changes have produced a new seismic shock to the Italian party system. A significant alteration in the balance of power among the three main poles, both at national level and within each of the different geopolitical areas of the country - leading in the substantial diminishing of vote nationalization - has clearly occurred.

The overall picture is that of a persistent state of de-institutionalization that maintains the party system in a condition of enduring unpredictability regarding the ultimate direction its transformation is to take. At present, it appears that this process of change may lead in one of two alternative directions: either a consolidation of the tripolar party system that has emerged since 2013, or the start of a new bipolar phase in Italian politics.

Indeed, in purely numerical terms, data show that the index of bipolarism (sum of the vote/seat shares of the two most voted coalitions, centre-right and M5S in 2018) has reached 69.7\% in terms of votes (compared to $58.7 \%$ in 2013, when the two main poles were centre-right and centre-left), and $79.6 \%$ in terms of seats (75\% in 2013). It is too early to say whether this is just a rebalancing of three stable forces, or in fact the beginning of a transition towards a new bipolar competition, this time centred around two different political forces (the M5S and Lega in place of the PD and FI). Nonetheless, by comparing the 2018 election with the 1994 election (which is usually considered to represent the start of the bipolar era), the two main poles' share of the vote is almost 11 points lower, and the third pole is about 7 points stronger than in 1994. Hence, data seem to suggest that a new bipolar pattern of competition is not around the corner just yet, provided that the centre-left coalition does not collapse in the short term. Given the extreme fluidity of the Italian party and electoral environment, this latter development should not be precluded entirely.

Even though the final result of this process of change is still very unclear, it is likely that it will be affected by the formation of the M5S-Lega government, which occurred after three months of complex negotiations. Now the two main populist parties are in power. This is a real novelty not only in the Italian but also in the Western European context. Moreover, the two mainstream parties - PD and $\mathrm{FI}$ - have been put together in opposition for the first time since 1994. This new government-opposition dynamics may even lead to the progressive strengthening of the 
'globalization' (Kriesi et al. 2012) or 'transnational' cleavage (Hooghe and Marks 2018) at the expense of the traditional left-right pattern of conflict. This new division line opposing, on one side, Eurosceptic, anti-immigrants and anti-globalization parties and, on the other side, Europhile, promulticulturalism and pro-globalization parties is gaining momentum in many Western European countries, but Italy is the only one where the former stand alone in office. The possible restructuring of the Italian party system along this new division line may contribute to create a new bipolar setting, but may also have consequences going beyond the domestic context. If the Eurosceptic parties continue to prevail, the Italy-EU relationships will undergo increasing tensions and put at risk the very existence of the Union as it has been so far.

\section{References}

Bochsler, D. (2010) 'Measuring party nationalisation: A new Gini-based indicator that corrects for the number of units', Electoral Studies, vol. 29, pp. 155-168.

Caramani, D. (2004) The nationalization of politics: The formation of national electorates and party systems in Western Europe, Cambridge, Cambridge University Press.

Casal Bértoa, F. (2014) 'Party systems and cleavage structures revisited: A sociological explanation of party system institutionalization in East Central Europe', Party Politics, vol. 20, no. 1, pp. 1636.

Casal Bértoa F., Deegan-Krause, K. \& Haughton, T. (2017) 'The volatility of volatility: Measuring change in party vote shares', Electoral Studies, vol. 50, pp. 142-156.

Ceccarini, L. \& Bordignon, F. (2017), 'Referendum on Renzi: The 2016 vote on the Italian constitutional revision', South European Society and Politics, vol. 22, no. 3, pp. 281-302.

Chiaramonte, A. (2015) 'The unfinished story of electoral reforms in Italy', Contemporary Italian Politics, vol. 7, no. 1, pp. 10-26.

Chiaramonte, A. \& De Sio, L. (eds.) (2014) Terremoto elettorale. Le elezioni politiche del 2013, Bologna, II Mulino.

Chiaramonte, A. \& Emanuele, V. (2014) 'Bipolarismo Addio? II Sistema Partitico tra Cambiamento e De-Istituzionalizzazione', in Terremoto elettorale. Le elezioni politiche del 2013, eds. A. Chiaramonte \& L. De Sio, Bologna, II Mulino, pp. 233-262. 
Chiaramonte, A. \& Emanuele V. (2017) 'Party system volatility, regeneration and deinstitutionalization in Western Europe (1945-2015)', Party Politics, vol. 23, no. 4, pp. 376-388. D'Alimonte, R. (2013) 'The Italian elections of February 2013: the end of the Second Republic?', Contemporary Italian Politics, vol. 5, no. 2, pp. 113-129.

D'Alimonte, R., Di Virgilio, A. \& Maggini, N. (2013), 'I risultati elettorali: bipolarismo addio?', in Voto amaro. Disincanto e crisi economica nelle elezioni del 2013, ed Itanes, Bologna, II Mulino, pp. $17-32$

Deseriis, M. (2017), 'Direct Parliamentarianism: An Analysis of the Political Values Embedded in Rousseau, the 'Operating System' of the Five Star Movement', eJournal of eDemocracy and Open Government, vol. 9, no. 2.

De Sio, L. (ed) (2011) La politica cambia, i valori restano? Una ricerca sulla cultura politica dei cittadini toscani, Florence, Florence University Press.

De Sio, L. \& Paparo, A. (ed) (2018) The year of challengers? Issues, public opinion, and elections in Western Europe in 2017, Rome, Centro Italiano Studi Elettorali.

Diamanti, I. (2009) Mappe dell'Italia Politica: Bianco, rosso, verde, azzurro e... tricolore, Bologna, II Mulino.

Emanuele, V. (2015a) 'Dataset of electoral volatility and its internal components in Western Europe (1945-2015)', CISE, http://cise.luiss.it/cise/dataset-of-electoral-volatility-and-its-internalcomponents-in-western-europe-1945-2015/.

Emanuele, V. (2015b) 'Vote (de)-nationalisation and party system change in Italy (1948-2013)', Contemporary Italian Politics, vol. 7, no. 3, pp. 251-272.

Emanuele, V. (2018) Cleavages, institutions, and competition. Understanding vote nationalization in Western Europe (1965-2015), London: Rowman and Littlefield/ECPR Press.

Emanuele, V. \& Chiaramonte, A. (2016) 'A growing impact of new parties: myth or reality? Party system innovation in Western Europe after 1945', Party Politics, doi:10.1177/1354068816678887.

Galli, G., Capecchi, V., Cioni Polacchini, V., \& Sivini, G. (1968) I/ comportamento elettorale in Italia, Bologna, II Mulino.

Goodman, L.A. (1953) 'Ecological regression and behavior of individual', American Sociological Review, vol. 18, pp. 663-664.

Hooghe, L. \& Marks, G. (2018), 'Cleavage theory meets Europe's crises: Lipset, Rokkan, and the transnational cleavage', Journal of European Public Policy, vol. 25, no. 1, pp. 109-135. 
Kriesi, H., Grande, E., Dolezal, M., Helbling, M., Höglinger, D., Hutter, S., \& Wüest, B. (2012), Political conflict in Western Europe, Cambridge: Cambridge University Press.

Laakso, M. \& Taagepera, R. (1979) 'The effective number of parties: a measure with application to West Europe', Comparative Political Studies, vol. 12, pp. 3-27.

Lupu, N. (2015) 'Nacionalizacion e institucionalizacion de partidos en la Argentina del siglo XX', in Institucionalizacion de los Sistemas de Partidos en America Latina: Causas y Consecuencias, ed. M. Torcal, Buenos Aires, Anthropos/Siglo XXI.

Maggini, N. \& De Lucia, F. (2014) 'Un successo a 5 stelle', in Terremoto elettorale. Le elezioni politiche del 2013, eds. A. Chiaramonte \& L. De Sio, Bologna, II Mulino, pp. 173-201.

Mainwaring, S. \& Scully T.R. (1995) Building Democratic Institutions: Party Systems in Latin America, Stanford, Stanford University Press.

Pedersen, M.N. (1979) 'The dynamics of European party systems: changing patterns of electoral volatility', European Journal of Political Research, vol. 7, pp. 1-26.

Sani, G. (1992) '1992: la destrutturazione del mercato elettorale', Rivista Italiana di Scienza Politica, vol. 22, pp. 237-286.

Sartori, G. (1976) Parties and Party Systems: A framework for analysis, New York, Cambridge University Press.

Schadee, H.M.A. \& Corbetta, P.G. (1984) Metodi e modelli di analisi dei dati elettorali, Bologna, II Mulino.

Stokes, D. (1963) 'Spatial Models of Party Competition', American Political Science Review, vol. 57, no. 2, pp. 368-377.

Tarchi, M. (2015), L'Italia populista. Dal qualunquismo a Beppe Grillo, Bologna, II Mulino.

Tarchi, M. (2018) 'Voters without a Party: The 'Long Decade' of the Italian Centre-Right and its Uncertain Future', South European Society and Politics, vol. 23, no. 1, pp. 147-162.

Tronconi, F. (2009) I partiti etnoregionalisti: Ia politica dell'identità territoriale in Europa occidentale, Bologna, II Mulino.

Verbeek, B., Zaslove, A. \& Rooduijn, M. (2018), 'Italian populism: Toppling and re-building the party system twice', in Absorbing the blow: populist parties and their impact on parties andparty systems, ed. A. Zaslove \& S. Wolinetz, London, Rowman \& Littlefield, pp. 197-222. 
Left

Centre-Left

Centre

Centre-Right

Right

Out of the $L / R$ dimension
Rivoluzione Civile (2.3\%)

Bersani Coalition (29.6\%) Sinistra Ecologia Libertà (3.2\%)

Partito Democratico (25.4\%)

Centro Democratico (0.5\%)

Südtiroler Volkspartei $(0.4 \%)$

\begin{tabular}{|c|}
\hline Monti Coalition (10.6\%) \\
Scelta Civica $(8.3 \%)$ \\
Unione di Centro $(1.8 \%)$ \\
Futuro e Libertà $(0.5 \%)$ \\
\hline Berlusconi Coalition $(29.2 \%)$ \\
II Popolo della Libertà $(21.6 \%)$ \\
Lega Nord $(4.1 \%)$ \\
Fratelli d'Italia $(2.0 \%)$ \\
6 minor allies $(1.5 \%)$ \\
\hline
\end{tabular}

Movimento 5 Stelle (25.6\%)
Liberi e Uguali

Partito Democratico

Insieme

Più Europa

Südtiroler Volkspartei

Civica Popolare

Noi con I'Italia - Unione di Centro

Forza Italia

Lega

Fratelli d'Italia

Figure 1 Parties and coalitions competing in the 2013 and 2018 Italian general elections. In parentheses 2013 Chamber results are reported.

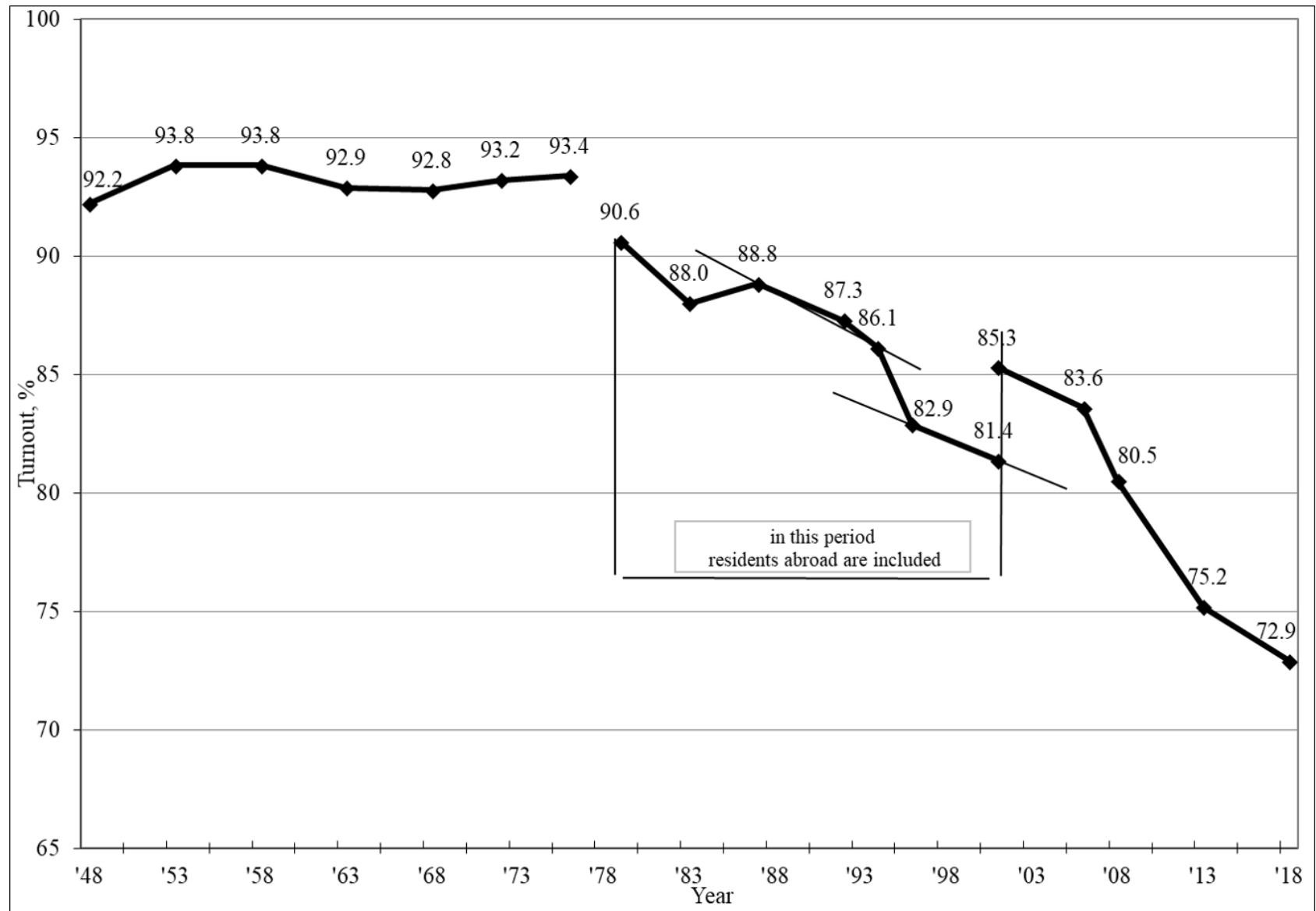


Figure 2 Turnout in Italy since 1948.

\section{Source: Ministry of the Interior}

a Percentages are relative to the whole set of registered voters between 1979 and 2001, to only registered voters living in Italy until 1976 and since 2001. For 2001, then, we report both percentages: 85.3 is relative to Italian residents only, 81.4 is relative to the whole set of registered voters (thus both those living in Italy and abroad). This is done to show the negative effect on turnout which the inclusion of the latter constituency had in the previous period.
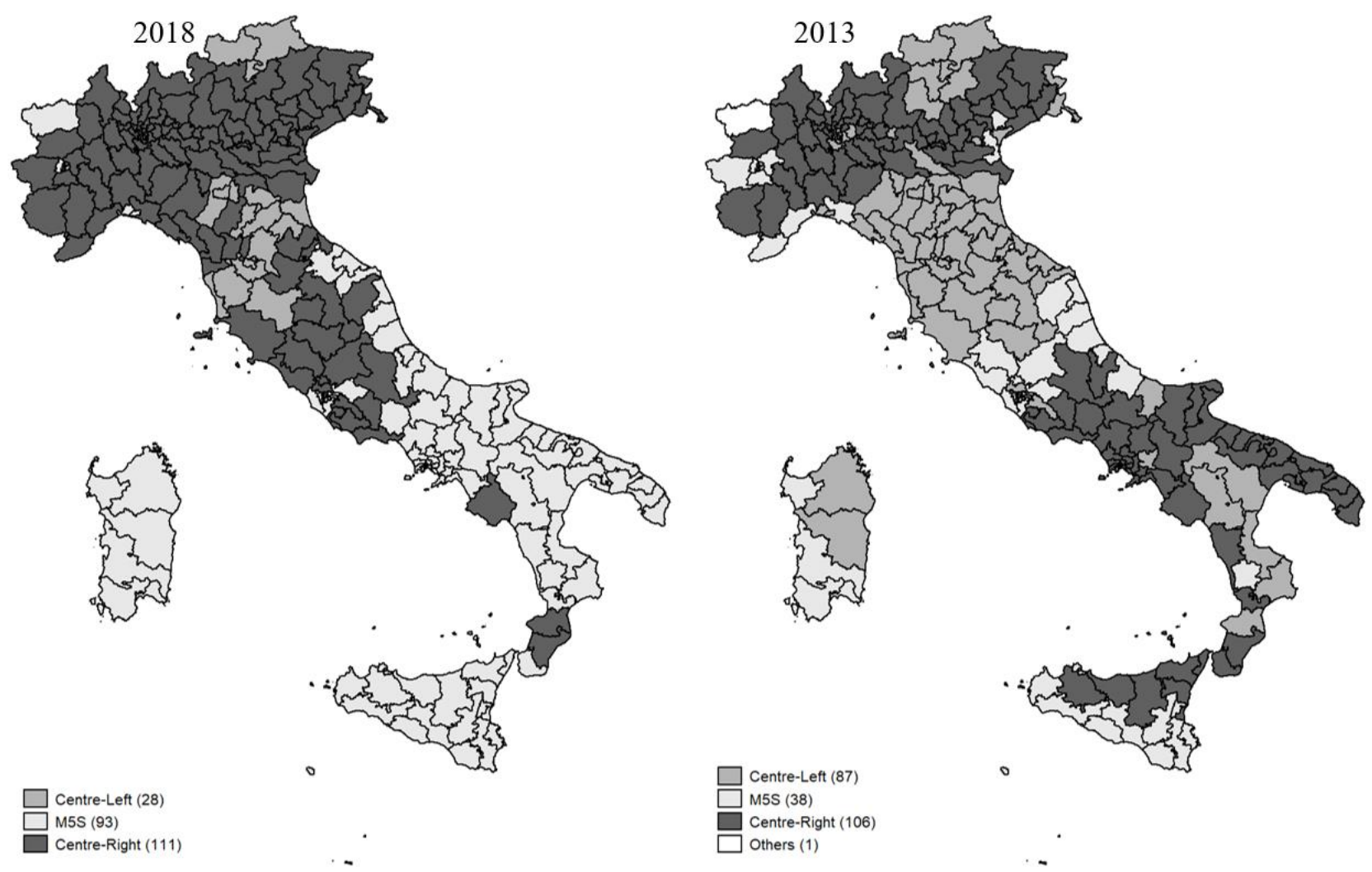

Figure 3 Most voted coalition/party in the SMDs (2018 and 2013 compared).

Source: own calculations based on Ministry of the Interior data 


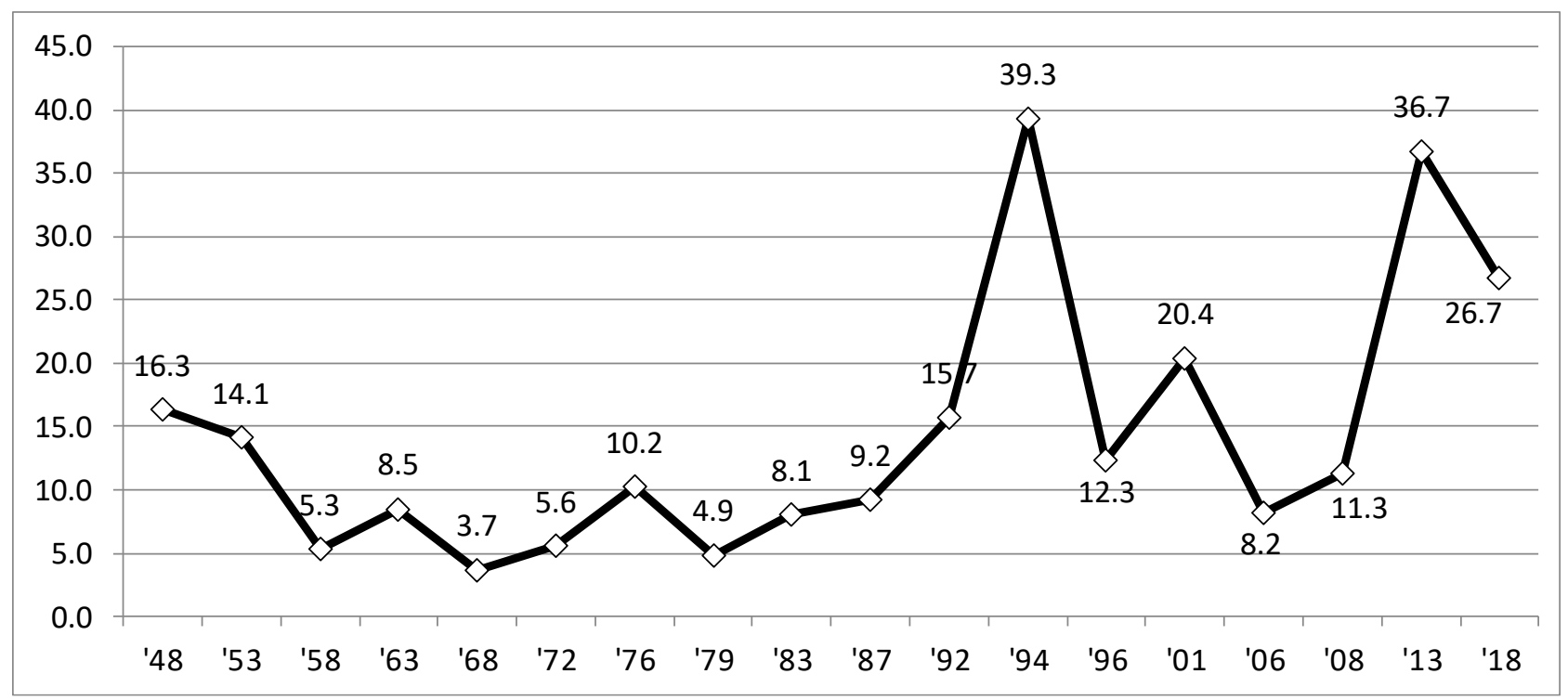

Figure 4 Evolution of electoral volatility, Chamber of Deputies (1948-2018).

Source: For 2018, our own calculations based on official electoral results; for the period 1948-2013, Emanuele (2015a).

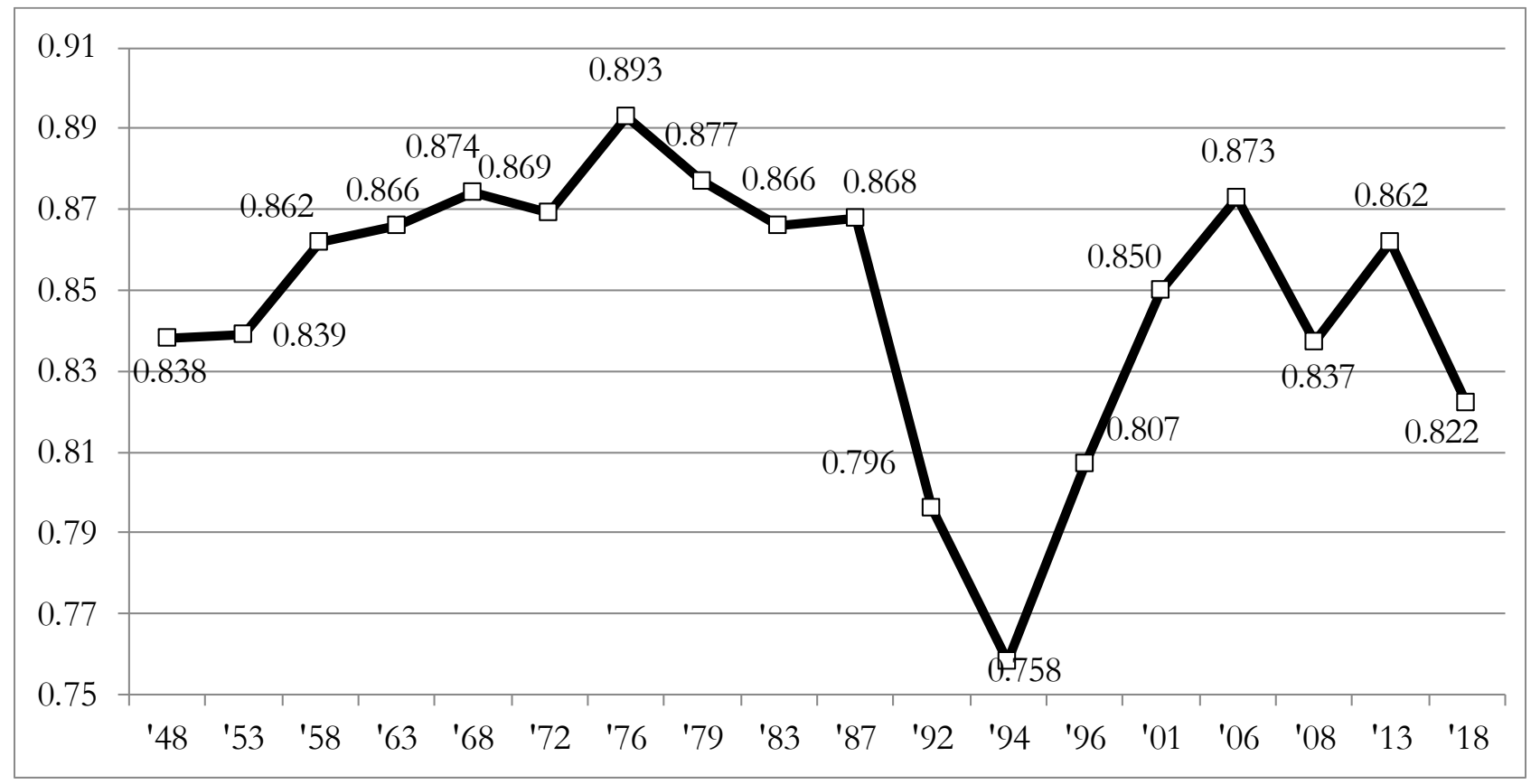

Figure 5 Evolution of vote nationalization, Chamber of Deputies (1948-2018).

Source: For 2018, our own calculations based on official electoral results; for the period 1948-2013, Emanuele (2015b; 2018). 
Table 1 Results of the 2018 general election (Chamber of Deputies and Senate)

\begin{tabular}{|c|c|c|c|c|c|c|c|c|c|c|c|c|}
\hline \multirow[b]{3}{*}{ Lists and coalitions } & \multicolumn{6}{|c|}{ Chamber of Deputies } & \multicolumn{6}{|c|}{ Senate } \\
\hline & \multicolumn{2}{|c|}{ Votes } & \multicolumn{4}{|c|}{ Seats } & \multicolumn{2}{|l|}{ Votes } & \multicolumn{4}{|c|}{ Seats } \\
\hline & No. & $\%$ & $\mathrm{PR}$ & FPTP & Abroad & Total & No. & $\%$ & PR & FPTP & Abroad & Total \\
\hline Lega & $5,705,925$ & 17.3 & 73 & 50 & 2 & 125 & $5,334,049$ & 17.6 & 37 & 21 & - & 58 \\
\hline Forza Italia (FI) & $4,586,672$ & 13.9 & 59 & 43 & 1 & 103 & $4,358,101$ & 14.4 & 33 & 22 & 2 & 57 \\
\hline Fratelli d'Italia (FDI) & $1,440,107$ & 4.4 & 19 & 13 & - & 32 & $1,286,887$ & 4.3 & 7 & 11 & - & 18 \\
\hline Noi con I'Italia-UdC (NCl-UDC) & 431,042 & 1.3 & 0 & 5 & 0 & 5 & 362,131 & 1.2 & 0 & 4 & 0 & 4 \\
\hline FI-Fdl-Mov.Nuova Valle D'Aostaa & 5,533 & 0.0 & - & 0 & - & 0 & 5,223 & 0.0 & - & 0 & - & 0 \\
\hline Total Centre-Right & $12,169,279$ & 37.0 & 151 & 111 & 3 & 265 & $11,346,391$ & 37.5 & 77 & 58 & 2 & 137 \\
\hline Movimento 5 Stelle (M5S) & $10,748,372$ & 32.7 & 133 & 93 & 1 & 227 & $9,747,701$ & 32.2 & 68 & 44 & 0 & 112 \\
\hline Partito Democratico (PD) & $6,153,081$ & 18.7 & 86 & 21 & 5 & 112 & $5,788,103$ & 19.1 & 43 & 8 & 2 & 53 \\
\hline +Europa & 845,406 & 2.6 & 0 & 2 & 1 & 3 & 716,136 & 2.4 & 0 & 1 & 0 & 1 \\
\hline Insieme & 191,489 & 0.6 & 0 & 1 & - & 1 & 163,903 & 0.5 & 0 & 1 & - & 1 \\
\hline Civica Popolare (CP) & 180,539 & 0.5 & 0 & 2 & 0 & 2 & 152,505 & 0.5 & 0 & 1 & 0 & 1 \\
\hline SVP-PATT & 134,613 & 0.4 & 2 & 2 & - & 4 & 128,336 & 0.4 & 1 & 2 & - & 3 \\
\hline PD-UV-UVP-EPAVb & 14,429 & 0.0 & - & 0 & - & 0 & 15,958 & 0.1 & - & 1 & - & 1 \\
\hline Total Centre-Left & $7,519,557$ & 22.9 & 88 & 28 & 6 & 122 & $6,964,941$ & 23.0 & 44 & 14 & 2 & 60 \\
\hline Liberi e Uguali (LEU) & $1,114,298$ & 3.4 & 14 & 0 & 0 & 14 & 990,715 & 3.3 & 4 & 0 & 0 & 4 \\
\hline Others & $1,354,919$ & 4.1 & 0 & 0 & 2 & 2 & $1,226,064$ & 4.0 & 0 & 0 & 2 & 2 \\
\hline TOTAL & $32,906,425$ & 100 & 386 & 232 & 12 & 630 & $30,275,812$ & 100 & 193 & 116 & 6 & 315 \\
\hline
\end{tabular}

Source: Supreme Court for results in the domestic arena (except Aosta Valley), Ministry of the Interior for results in the Aosta Valley and seats abroad.

a Electoral coalition between FI, FDI and a local movement in the Aosta Valley.

${ }^{\mathrm{b}}$ Electoral coalition between PD and ethno-regionalist parties in the Aosta Valley. 
Table 2 Vote shifts between 2013 and 2018 in 11 Italian cities: main destinations of disloyal voters ${ }^{\mathrm{a}}$

\begin{tabular}{|c|c|c|c|c|c|c|c|c|c|c|}
\hline & \multicolumn{10}{|c|}{2013 Electorates } \\
\hline & \multicolumn{2}{|c|}{ Centre-left led by Bersani } & \multicolumn{2}{|c|}{ Centre led by Monti } & \multicolumn{2}{|c|}{ Centre-right led by Berlusconi } & \multicolumn{2}{|c|}{ M5S } & \multicolumn{2}{|c|}{ Non-voters } \\
\hline & $\begin{array}{c}1 s t \\
\text { destination }\end{array}$ & $\begin{array}{c}\text { 2nd } \\
\text { destination }\end{array}$ & $\begin{array}{c}1 s t \\
\text { destination }\end{array}$ & $\begin{array}{c}\text { 2nd } \\
\text { destination }\end{array}$ & $\begin{array}{c}1 s t \\
\text { destination }\end{array}$ & $\begin{array}{c}\text { 2nd } \\
\text { destination }\end{array}$ & $\begin{array}{c}1 s t \\
\text { destination }\end{array}$ & $\begin{array}{c}\text { 2nd } \\
\text { destination }\end{array}$ & $\begin{array}{c}\text { 1st } \\
\text { destination }\end{array}$ & $\begin{array}{c}\text { 2nd } \\
\text { destination }\end{array}$ \\
\hline \multicolumn{11}{|l|}{ North } \\
\hline Turin & M5S (15\%) & LEU (13\%) & PD (45\%) & $\begin{array}{l}\text { PD allies } \\
(18 \%)\end{array}$ & $\begin{array}{c}\text { Non-voters } \\
(11 \%)\end{array}$ & PD (9\%) & Lega (23\%) & $\begin{array}{c}\text { Non-voters } \\
(10 \%)\end{array}$ & M5S (5\%) & FI (4\%) \\
\hline Genoa & M5S (17\%) & $\begin{array}{c}\text { Non-voters } \\
(13 \%)\end{array}$ & PD (39\%) & $\begin{array}{l}\text { PD allies } \\
(15 \%)\end{array}$ & $\begin{array}{c}\text { Non-voters } \\
(12 \%)\end{array}$ & PD (8\%) & Lega $(18 \%)$ & $\begin{array}{c}\text { Non-voters } \\
(5 \%)\end{array}$ & $\mathrm{FI}(4 \%)$ & Lega (3\%) \\
\hline Venice & M5S (20\%) & $\begin{array}{c}\text { LEU, Non- } \\
\text { voters (11\%) }\end{array}$ & PD (36\%) & FI (20\%) & $\begin{array}{c}\text { Non-voters } \\
(9 \%)\end{array}$ & PD, M5S (4\%) & Lega $(28 \%)$ & $\begin{array}{c}\text { Non-voters } \\
(3 \%)\end{array}$ & Lega (4\%) & Others (3\%) \\
\hline Padua & M5S (18\%) & LEU (12\%) & PD (43\%) & $\mathrm{FI}(11 \%)$ & $\begin{array}{c}\text { Non-voters } \\
(8 \%)\end{array}$ & M5S (3\%) & Lega (30\%) & $\begin{array}{c}\text { Non-voters } \\
(5 \%)\end{array}$ & None & None \\
\hline \multicolumn{11}{|c|}{ 'Red Zone' } \\
\hline $\begin{array}{l}\text { Reggio } \\
\text { Emilia }\end{array}$ & M5S (15\%) & LEU (11\%) & PD (29\%) & $\begin{array}{l}\text { PD allies } \\
(27 \%)\end{array}$ & $\begin{array}{c}\text { Non-voters } \\
(15 \%)\end{array}$ & M5S (12\%) & Lega $(18 \%)$ & $\begin{array}{c}\text { Non-voters } \\
(8 \%)\end{array}$ & $\mathrm{FI}(5 \%)$ & M5S (4\%) \\
\hline Rimini & $\begin{array}{c}\text { Non-voters } \\
(18 \%)\end{array}$ & $\begin{array}{l}\text { M5S, Lega } \\
(13 / 12 \%)\end{array}$ & PD (40\%) & $\begin{array}{l}\text { PD allies } \\
(14 \%)\end{array}$ & PD (12\%) & Non-voters (7\%) & Lega (21\%) & None & $\mathrm{FI}(5 \%)$ & $\begin{array}{c}\text { Lega, others } \\
(3 \%)\end{array}$ \\
\hline Prato & M5S (18\%) & $\begin{array}{c}\text { Non-voters } \\
(8 \%)\end{array}$ & PD (27\%) & FDI (16\%) & PD (6\%) & PD allies (3\%) & Lega $(26 \%)$ & $\begin{array}{c}\text { Non-voters } \\
(12 \%)\end{array}$ & M5S (12\%) & $\begin{array}{c}\text { Lega, others } \\
(3 \%)\end{array}$ \\
\hline \multicolumn{11}{|l|}{ South } \\
\hline Cagliari & M5S (21\%) & LEU (13\%) & PD (17\%) & $\begin{array}{l}\text { PD allies } \\
(12 \%)\end{array}$ & PD (12\%) & Non-voters (9\%) & $\begin{array}{c}\text { Non-voters } \\
(18 \%)\end{array}$ & Lega (7\%) & M5S (12\%) & Lega (4\%) \\
\hline Naples & M5S (22\%) & $\begin{array}{c}\text { Non-voters } \\
(15 \%)\end{array}$ & PD (35\%) & FI (23\%) & $\begin{array}{c}\text { Non-voters } \\
(27 \%)\end{array}$ & M5S (20\%) & Others (4\%) & $\begin{array}{c}\text { Non-voters } \\
(3 \%)\end{array}$ & M5S (22\%) & None \\
\hline $\begin{array}{l}\text { Reggio } \\
\text { Calabria }\end{array}$ & $\begin{array}{c}\text { Non-voters } \\
(34 \%)\end{array}$ & LEU (11\%) & $\begin{array}{l}\text { Others } \\
(35 \%)\end{array}$ & FDI (25\%) & $\begin{array}{c}\text { Non-voters } \\
(23 \%)\end{array}$ & PD allies (4\%) & Lega (5\%) & Others (4\%) & M5S (18\%) & FI (7\%) \\
\hline Messina & $\begin{array}{c}\text { Non-voters } \\
(44 \%)\end{array}$ & LEU (11\%) & PD (64\%) & Others (9\%) & $\begin{array}{c}\text { Non-voters } \\
(35 \%)\end{array}$ & M5S (6\%) & $\begin{array}{c}\text { Non-voters } \\
(5 \%)\end{array}$ & Lega (3\%) & M5S (28\%) & $\mathrm{FI}(8 \%)$ \\
\hline
\end{tabular}

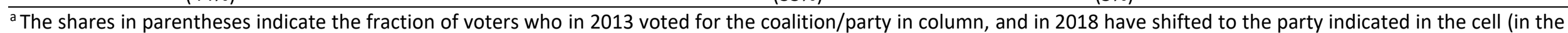

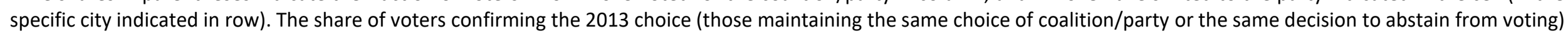
is not shown. 
